\title{
Classroom Teacher Candidates' Metaphoric Perceptions Regarding the Concepts of Reading and Writing: A Comparative Analysis
}

\author{
Emine Gül ÖZENÇ ${ }^{1} \&$ Mehmet ÖZENÇ \\ ${ }^{1}$ Niğde Ömer Halisdemir University Department of Elementary Education, Niğde, Turkey \\ ${ }^{2}$ National Ministry of Education Şehit Kemal Tosun Elementary School, Niğde, Turkey \\ Correspondence: Emine Gül ÖZENÇ, Niğde Ömer Halisdemir Üniversitesi Eğitim Fakültesi Temel Eğitim \\ Bölümü Sınıf Eğitimi ABD Merkez Yerleşke Bor Yolu Üzeri, NIĞDE 51240, Turkey. E-mail: \\ egozenc@ohu.edu.tr
}

Received: August 20, 2017

Accepted: November 16, 2017

Online Published: December 22, 2017

doi:10.5539/ies.v11n1p100

URL: https://doi.org/10.5539/ies.v11n1p100

\begin{abstract}
The purpose of this study is to determine and compare candidate classroom teachers' metaphoric perceptions about reading and writing. The study was conducted with teacher candidates who were studying at Ömer Halisdemir University's Department of Elementary Education in Niğde/Turkey during 2016-2017 academic year. A total of $2661^{\text {st }}, 2^{\text {nd }}, 3^{\text {rd }}$ and $4^{\text {th }}$ grade candidate classroom teachers participated in the study. The study design was organized according to phenomenological design. According to the study findings, teacher candidates created 23 metaphoric categories in reading, 17 in writing and 15 in both reading and writing. The most categories developed by classroom candidate teachers on the concept of reading is necessity. As to writing; the most categories developed by classroom candidate teachers on the concept of writing is on expressing feelings. The category with the least metaphor about writing concept is the negativity and watching. The common metaphors used by the classroom teacher candidates regarding the concepts of reading and writing are mostly gathered in the categories of water and its derivatives and life. Whereas the category with the least common metaphors about is infinity. Another result of the research is that the teacher candidates produce a more negative number of metaphorical concepts in the writing concept. Metaphors on the concept of writing are outpouring, effusion and the man himself. As a result, metaphors can be used as a research tool to determine teacher candidates' perceptions and opinions about reading and writing.
\end{abstract}

Keywords: metaphor, reading and writing, comparison

\section{Introduction}

Throughout people's lives, there are certain skills that they use all the time and that they have used since elementary school. The first skills that come to mind among these are no doubt the reading and writing skills because if these skills were not acquired effectively, even daily lives will be limited, and life quality will decrease. Prerequisites for literacy and functional literacy, these skills have a big role in people's lives.

Reading is important in terms of people fulfilling themselves and maintaining their lives and in terms of being used as a primary acquisition and sharing tool among all the educational fields starting from elementary school to higher education (Maden, 2012).

Looking at the related literature, it is seen that there are many definitions regarding readings and that these definitions include different characteristics of reading. Reading is the activity of making meaning from written symbols by working psychomotor skills with cognitive behaviors (Razon, 1980). According to Akyol (2005, p. 1), reading is the process of meaning making in which prior knowledge is used in an organized environment in line with appropriate method and purpose based on effective communication between the writer and the reader. Kavcar, Oğuzkan and Sever (1997, p. 41) define reading as the process of seeing, perceiving and comprehending a writing with its words, sentences, punctuation marks and other elements. Özdemir (2011, p. 11) describes reading as perceiving, meaning making, comprehending and interpreting printed or written words through the sense organs. Also, reading is the coding of a number of print-based elements and the thinking skills needed to understand a text (Harris \& Hodge, 1995). As is seen, there are various definitions made regarding reading.

Starting from the first years of elementary school to the last years of schooling, reading and reading 
comprehension are important factors for people's success (Ünüvar \& Çelik, 1999). The richness of reading reflects on people's worlds of thought and their lives. In addition, behaviors and worlds of thought of individuals who read are different. While reading constitutes the basis for information acquisition, it also forms the basis for critical thinking and interpretation. If people make effort to improve themselves instead of making effort to age, they will be more productive (Ungan, 2008). There are, no doubt, many benefits of reading for people. Reading allows people to learn new words, gain new insights, imagine new dreams and expand their horizons by improving their creativity (Akyol, 2008).

As is known, learning happens mostly through reading. Students who do not have the habit of reading and who do not comprehend what they read are not expected to be successful in their classes, to develop their vocabulary and to gain new experiences (Ünalan, 2006).

Reading is an exciting way for people to better understand their experiences and to discover themselves. Reading is one of the most effective tools in the systematic development of language and personality (Pala \& Yildiz, 2012, p. 15). In addition to helping people increase their knowledge, reading helps people to develop different perspectives, to increase their ability to interpret life and to improve their speaking and writing skills (Gün, 2012). Therefore, the concept of reading is also related to other language skills like listening, speaking and writing. Starting from this point of view, it can be said that someone who reads a lot can also write well. In a study conducted by Eroğlu (2013), the relationship between teacher candidates' reading habits and accurate writing skills was found positive, and students who read more frequently were successful in written expression. Similarly, in his study, Clark (2010) put forth that there is a relationship between handwriting and early literacy skills.

One of the four basic language skills, writing is a product of thought. Thought is a sum of products that emerge as a result of certain accumulation. When a writing is finished and presented for use, there is no possibility to come back and revise (Yıldız, Okur, Arı, \& Yılmaz, 2006, p. 203). According to Güneş (2007, p. 107), writing is the transfer of information that is constructed in the mind to writing. The writing process happens through construction in the mind, and this process ends with thoughts being transferred to writing. For this to happen, it is necessary to construct in the brain by understanding well what is said and read. The writing process starts with reviewing the constructed information in the brain. Then, the information that will be written is selected by determining the writing's purpose, method, subject and limitations. Later, the selected information that goes through various cognitive processes is transformed into letters, syllables, words and sentences (Güneş, 2007). Akyol (2000: 146) defined the writing skills as the use of symbols and signs necessary for expressing thoughts and as production of thought that is readable. In the Primary Turkish Education Curriculum (Meb, 2005: 22), writing skill is explained as follows: "Writing is the written expression of feelings, thoughts, desires and plans. Making up an important part of Turkish education, writing requires skills in addition to knowledge. These skills are gained by practice. Writing skills is directly related to the reading skills. The development of students' writing skills depends on continuous reading, writing, examining and discussing their writing, and finding and using the expressions they like".

Metaphor is described as a simile in the Turkish dictionary and defined as "the use of a word or a concept in a way other than its accepted meaning" (TDK, 2011, p. 1641). Saban (2008, p. 460) argued that the concept of metaphor symbolizes cognitive and intellectual comprehension system and that it has a literary and artistic functions like other simile arts (for example, comparison, simile, allegory, etc.) used in metaphorical literature. Metaphors help the expression to remain vivid and exciting (Altun, 2003, pp. 1-5). The word metaphor is derived from the word "metapherein", which is formed by the combination of the Greek word "meta" (change) and "hperein" (transfer) (Levine, 2005, p. 172).

Metaphors are how one expresses a concept or a phenomenon by using analogies (Aydın, 2010, p. 1296). Metaphors are considered tools to explain life, environment, events and objects by using different analogies (Cerit, 2008, p. 694). The use of metaphors improves people's creativity by associating the unknown with the known and by creating new associations between concepts (Aydoğdu, 2008, p. 27). Conducting the first studies on metaphors, the Greek philosopher Aristotle defined metaphor as a word string comparing two or more objects that are not exactly alike (Angus \& Rennie, 1988 cited in Karairmak \& Güloğlu, 2012). Also, Bruner (1979, p. 63) explains metaphor as people expressing their different experiences deeper and more emotionally through images.

Some of the basic functions of metaphors are grasping, interpreting and transferring a large number of data and information, perceiving new information and coping with uncertainty (Petrie \& Oshlag, 1993 cited in Ekiz \& Koçyiğit, 2013). Metaphors are generally regarded as just a figure of speech and in this sense it appears to be 
related to language and the use of language (Yıldırım \& Şimşek, 2013) but its importance is more than this. When words are not enough, individuals express some of their inner thoughts and feelings with metaphors in the outer world (Zuniga, 1992).

In literature, there are many studies on metaphors discussing different topics. Some of these studies are about students (Aydın \& Sulak, 2015; Bektaş, Okur, \& Karadağ, 2014, Gömleksiz, Kan, \& Öner, 2012; Kahyaoğlu, 2015; Soysal \& Afacan, 2012; Kırmızı \& Çelik, 2015; Korkmaz \& Bağçeci 2013; Oflaz, 2011; Şahin \& Tüzel, 2014; Yalçın \& Erginer, 2012;); some on teacher candidates (Aydın, 2011; Aydın \& Yalmanc1, 2013; Geçit \& Gencer, 2011; İlter, 2015; Kalyoncu, 2013; Ulusoy, 2013; Yalçınkaya, 2013; Yılmaz, Göçen \& Yılmaz, 2013) some on teachers (Ekiz \& Koçyiğit, 2013; Ünal, Yıldırım \& Çelik, 2010); some on administrators (Ünal, Yıldırım \& Çelik, 2010); and some on counselors (Karaırmak \& Güloğlu, 2012). However, it is seen that there are no two-way comparative metaphorical studies. In this sense, this study will be the first one to bring a different perspective to the literature by a metaphorical view. Metaphors attract today's educators as it appeals to the individual's own world to understand and to configure as a powerful mental mapping and modeling mechanism (Arslan \& Bayrakçı, 2006). In this study, classroom teacher candidates' metaphorical views on the concepts of reading and writing were discussed and comparisons were made.

\section{Purpose}

The sub-purposes developed for the study's purpose are as follows:

1) What are classroom teacher candidates' metaphors regarding the concept of reading?

2) What are classroom teacher candidates' metaphors regarding the concept of writing?

3) What are the categories classroom teacher candidates use regarding the concepts of reading and writing?

4) How are classroom teacher candidates' metaphorical perceptions regarding the concepts of reading and writing negative?

\section{Method}

The study is designed as a phenomenological inquiry, one of the qualitative research methods. Phenomenology aims to put forth the phenomena that people encounter in their daily lives as experiences, perceptions and tendencies. People are aware of these phenomena but do not have in-depth and thorough understanding of them (Yıldırım \& Şimşek, 2013). In the study, the data were analyzed by content analysis.

\section{Study Group}

The study was carried with teacher candidates who were studying at the Department of Elementary Education of Niğde Ömer Halisdemir University's Faculty of Education, Turkey during the academic year of 2016-2017. 266 first-, second-, third- and fourth-year students participated in the study.

Table 1. Distribution of the study group according to sex

\begin{tabular}{lc}
\hline Sex & Number \\
\hline Male & 49 \\
Female & 217 \\
Total & 266 \\
\hline
\end{tabular}

The majority of the study group is made up of female (217) students.

Table 2. Distribution of the study group according to years

\begin{tabular}{lc}
\hline Years & Number \\
\hline $1^{\text {st }}$-year & 70 \\
$2^{\text {nd }}$ year & 97 \\
$3^{\text {rd }}$ year & 44 \\
$4^{\text {th }}$ year & 55 \\
Total & 266 \\
\hline
\end{tabular}

The majority of the study group is made of second-year students. 


\section{Data Collection}

A form was developed by the researcher in order to determine participating classroom teacher candidates' perceptions about the concepts of reading and writing. The students were asked to fill out personal information about certain variables in the first section. In the second section, they were asked to complete the statements "Reading is like ... because ..." and "Writing is like ... because ...". According to Yıldırım and Şimşek (2005, p. 213), "analogies alone cannot reveal the descriptive and visual power of metaphors. Following this, it is absolutely necessary to ask the reason. The power of analogies is really in this section which is related to the adjectives". For this reason, the students developed both metaphors and their reasons for the metaphors they used. This was carried out for each year in one class hour. Later, the writings of the students were collected and analyzed after the necessary steps.

\section{Data Analysis}

Students' perceptions regarding the concepts of reading and writing were evaluated through content analysis. In this process, the related analysis and process were carried out by examining many studies where metaphor analysis was used. According to Yıldırım and Şimşek (2005, p. 227), the data that were summarized and interpreted during the descriptive analysis was subjected to a more detailed process, and the concepts and themes that could not be determined through a descriptive approach can be discovered through this analysis. The basic process in content analysis is to bring together similar data within the framework of specific concepts and themes and to interpret these by organizing them in a way that readers can understand (Y1ldırım \& Şimşek, 2002, p. 227). Before data analysis were made, the forms that were filled out by the teacher candidates were numbered. Then, in order to easily identify the metaphors, the metaphors written by the participants were color coded for the concept of reading and the concept of writing separately. Later, during the classification stage, a sorting process took place. The forms of the students who could not develop a metaphor, who gave explanations by providing their own views and who could not write reasons for their metaphors were eliminated and were not included in the study. In this way, the number of papers that were 320 initially fell down to 266 papers. During the category development stage, the developed metaphors were examined in terms of common characteristics, and conceptual categories were created and grouped. The reasons students provided for their metaphors were also taken into consideration while developing categories. Afterwards, the related data were entered in the excel program in the computer environment, and percentage frequency values were calculated.

In addition to these, the validity and reliability analysis of the study were performed. For this, two experts grouped the metaphors under categories. These categories were matched with the categories developed by the researcher. After comparing these categories, the consensus and dissidence numbers were determined. Miles and Huberman's (1994) formula (Reliability = consensus/dissidence) was used to calculate the reliability coefficient. According to this, the reliability coefficient was found to be .958 .

\section{Findings}

In the present study, the metaphors developed by the classroom teacher candidates about the concepts of reading and writing are presented in the following tables in line with the study purposes.

Table 3. Metaphors developed by the classroom teacher candidates about the concepts of reading

\begin{tabular}{|c|c|c|c|c|c|c|c|c|}
\hline & Category & Metaphor & 1 & 2 & 3 & 4 & Total & Percentage \\
\hline \multirow{8}{*}{ Reading } & necessity & $\begin{array}{l}\text { water22, food3, to breath5, to eat } 2 \text {, medicine2, air2, to be } \\
\text { born1, to live3, to rest2, }\end{array}$ & 11 & 17 & 9 & 12 & 49 & 18.42 \\
\hline & saving & $\begin{array}{l}\text { Piggy bank1, map1, sapling2, experience } 5 \text {, money5, forest } 5 \text {, } \\
\text { tree } 18 \text {, stream5 }\end{array}$ & 8 & 18 & 11 & 5 & 42 & 15.79 \\
\hline & journey & $\begin{array}{l}\text { travel2, trip9, life journey12, adventure1, discovery4, } \\
\text { compass1, new life2 }\end{array}$ & 12 & 12 & 1 & 6 & 31 & 11.65 \\
\hline & Imagination-abstractness & dream7, imagination 9 & 7 & 6 & 0 & 3 & 16 & 6.02 \\
\hline & food & cofee 1 , ashure 1, ketchup 1, nameless food 11 & 3 & 6 & 3 & 2 & 14 & 5.26 \\
\hline & Infinity- continuity & sea4, ocean3, life3, sky1, space1, igniting gunpowder1, & 1 & 5 & 4 & 3 & 13 & 4.89 \\
\hline & originality-different worlds & $\begin{array}{l}\text { Different window4, using someone else's objects1, } \\
\text { experience2, horizon1, bees collecting pollen1, key1, ending } \\
\text { of a period1, abstraction2 }\end{array}$ & 4 & 3 & 2 & 4 & 13 & 4.89 \\
\hline & art & $\begin{array}{l}\text { Folk song2, activity5, to listen music2, to do needlework2, } \\
\text { song1 }\end{array}$ & 5 & 4 & 2 & 1 & 12 & 4.51 \\
\hline
\end{tabular}




\begin{tabular}{|c|c|c|c|c|c|c|c|c|}
\hline & temporariness & pleasure2, bird1, stars1, desire to live1, & 1 & 6 & 0 & 3 & 10 & 3.76 \\
\hline & light & sun5, light1, knowledge2 & 2 & 2 & 1 & 3 & 8 & 3.01 \\
\hline & tranquility & pencil1, paper1, theraphy5 & 0 & 2 & 4 & 1 & 7 & 2.63 \\
\hline & making meaning & Symbol1, carpentry1, making meaning of life 4 , world 1 & 2 & 1 & 1 & 3 & 7 & 2.63 \\
\hline & movement & sports 5 , to run 1 & 4 & 2 & 0 & 0 & 6 & 2.26 \\
\hline & health & baby 1 , development 5 & 2 & 1 & 1 & 2 & 6 & 2.26 \\
\hline & love & love 5 & 1 & 2 & 0 & 2 & 5 & 1.88 \\
\hline & limitation & cliff1, page4 & 2 & 2 & 0 & 1 & 5 & 1.88 \\
\hline & freedom & plane1, flying2, running away1 & 0 & 1 & 1 & 2 & 4 & 1.50 \\
\hline & Seeing-looking & $\begin{array}{l}\text { Looking at a scenery } 1 \text {, looking at a painting } 1 \text {, looking through } \\
\text { someone else's eyes } 2\end{array}$ & 2 & 0 & 2 & 0 & 4 & 1.50 \\
\hline & deservingness & jewelry 2 , friend 2 & 1 & 3 & 0 & 0 & 4 & 1.50 \\
\hline & dependence & To sleep1, radio1, not to be full up1, & 0 & 1 & 2 & 0 & 3 & 1.13 \\
\hline & Natural event & Wave1, snowball1, twister1 & 1 & 1 & 0 & 1 & 3 & 1.13 \\
\hline & negativity & difficult2 & 1 & 0 & 0 & 1 & 2 & 0.75 \\
\hline & watching & TV series, movie & 0 & 2 & 0 & 0 & 2 & 0.75 \\
\hline Total & & & 70 & 97 & 44 & 55 & 266 & 100.00 \\
\hline
\end{tabular}

When Table 3 is examined, it is seen that the metaphor classroom teacher candidates developed the most is water (f:22) under the necessity (f:49, 18.42\%) category. This is followed by the metaphor tree (f:18) under the saving (f:42, 15.79\%) category and the metaphor life journey (f:12) under the journey (f:31, 11.65\%) category. These are followed by the metaphor food (f:11) under the food (f:14, 5.26\%) category. It is also seen that the least metaphors are developed under the negativity and watching (f:2, $0.75 \%$ ) categories. The direct quotations about the metaphors and their reasons given by the teacher candidates are as follows:

- I think reading is like the world because it helps us to understand the world and the universe.

- I think reading is like the sun because it warms people and enlightens their world.

- I think reading is like the sea because it never finishes.

Table 4. Metaphors developed by the classroom teacher candidates about the concepts of writing

\begin{tabular}{|c|c|c|c|c|c|c|c|c|}
\hline & Category & Metaphor & 1 & 2 & 3 & 4 & Total & Percentage \\
\hline Writing & Expression of feelings - inner world & $\begin{array}{l}\text { light2, feeling1, skill1, man himself8, outpouring13, } \\
\text { spirit1, thought accumulation2, effusion12, family1, } \\
\text { theraphy2, to talk1, germination of a seed1, river3, } \\
\text { trust1, rain cloud1, psychologist1, number line1, } \\
\text { large body of water3, to cry1, blackboard1, tea1, } \\
\text { falls4, stream3, world of imagination2, mirror5 }\end{array}$ & 23 & 17 & 8 & 24 & 72 & 30.82 \\
\hline & comfort & $\begin{array}{l}\text { To sleep2, tranquility } 8 \text {, beauty } 4 \text {, medicine2, be going } \\
\text { great guns1, using one self's property } 2 \text {, house } 3 \text {, } \\
\text { freedom } 3\end{array}$ & 7 & 13 & 4 & 1 & 25 & 9.40 \\
\hline & permanence & $\begin{array}{l}\text { connection1, diamond1, embroidery1, memory1, } \\
\text { recollection1, historical work1, memorşes1, pencil2, } \\
\text { nail1, person1, scar1, signature1, line in life1, } \\
\text { document1, tattoo1, world history1, to scratch1, } \\
\text { concretization1, trace4, record1, seal1 }\end{array}$ & 3 & 12 & 3 & 7 & 25 & 9.40 \\
\hline & art & $\begin{array}{l}\text { painting4, craft2, weave carpet6, needlework4, } \\
\text { beautiful melody1, artist1 }\end{array}$ & 3 & 7 & 5 & 3 & 18 & 6.77 \\
\hline & completion & $\begin{array}{l}\text { Symbolisation1, movie5, work2, sentence2, } \\
\text { compositation1, home2 }\end{array}$ & 3 & 6 & 1 & 3 & 13 & 4.89 \\
\hline & negativity & $\begin{array}{l}\text { effort1, difficult7, rule1, occupation2, burst with } \\
\text { anger1, }\end{array}$ & 2 & 4 & 2 & 4 & 12 & 4.51 \\
\hline & necessity & power1, heart1, breath1, water8, phone1 & 1 & 4 & 2 & 5 & 12 & 4.51 \\
\hline & productivity-originality & & 3 & 7 & 2 & 0 & 12 & 4.51 \\
\hline & plant & tree5, seed3, sapling2, flower1 & 5 & 0 & 5 & 1 & 11 & 4.14 \\
\hline & friend & good friend5, friend6 & 6 & 4 & 0 & 1 & 11 & 4.14 \\
\hline
\end{tabular}




\begin{tabular}{|c|c|c|c|c|c|c|c|c|}
\hline & eating drinking & Food8, Turkish coffee1 & 2 & 4 & 3 & 0 & 9 & 3.38 \\
\hline & sensuality & love 7, to fall in love 1 , favour 1 & 2 & 4 & 2 & 1 & 9 & 3.38 \\
\hline & infinity & sky3, large body of water1, ocean3, & 0 & 3 & 2 & 2 & 7 & 2.63 \\
\hline & saving & $\begin{array}{l}\text { To craw11, machine1, construction5, rain1, sow } \\
\text { seed1, TV series1, bees making honey1, to let the fox } \\
\text { guard the henhouse1, stream3, fall1, pencil, river1 }\end{array}$ & 0 & 3 & 2 & 1 & 6 & 2.26 \\
\hline & to guide- journey & plane 1 , to travel 4 & 2 & 1 & 1 & 1 & 5 & 1.88 \\
\hline & experience & Life itself3, life1, world1, & 4 & 0 & 1 & 0 & 5 & 1.88 \\
\hline & movement & To do sports1, to run3 & 0 & 0 & 0 & 3 & 4 & 1.50 \\
\hline Total & & & 70 & 97 & 44 & 55 & 266 & 100.00 \\
\hline
\end{tabular}

When Table 4 is examined, it is seen that the most metaphors were developed under the by the expression of feelings - inner world category (f:72, 30.82\%). This followed by the permanence and comfort categories ( $\mathrm{f}: 25$, $9.40 \%)$, and later by the art category (f:18, 6.77\%). The least metaphors were developed under the movement category (f:4, 1.5\%). The direct quotations about the metaphors and their reasons given by the teacher candidates are as follows:

- I think writing is like a stream because it becomes clear as it flows.

- I think writing is like a mirror because it reflects what is inside.

- I think writing is like an occupation because it is tiring.

Table 5. Categories developed by the classroom teacher candidates about common concepts for reading and writing

\begin{tabular}{|c|c|c|c|c|c|c|c|}
\hline Category & Category & 1 & 2 & 3 & 4 & Total & percentage \\
\hline \multirow{15}{*}{$\begin{array}{l}\text { Common Concepts for } \\
\text { Reading and Writing }\end{array}$} & Water derivatives & 10 & 7 & 6 & 19 & 42 & 15.79 \\
\hline & life & 10 & 16 & 7 & 9 & 42 & 15.79 \\
\hline & Art related & 6 & 15 & 5 & 2 & 28 & 10.53 \\
\hline & Imagination-abstractness & 5 & 7 & 1 & 7 & 20 & 7.52 \\
\hline & journey & 8 & 9 & 1 & 2 & 20 & 7.52 \\
\hline & Eating-drinking & 5 & 6 & 5 & 2 & 18 & 6.77 \\
\hline & tranquility & 4 & 9 & 4 & 0 & 17 & 6.39 \\
\hline & Expression of feeling-inner world & 8 & 5 & 2 & 2 & 17 & 6.39 \\
\hline & necessity & 4 & 7 & 2 & 3 & 16 & 6.02 \\
\hline & saving & 2 & 4 & 2 & 2 & 10 & 3.76 \\
\hline & sensuality & 1 & 4 & 2 & 3 & 10 & 3.76 \\
\hline & negativity & 3 & 3 & 0 & 2 & 8 & 3.00 \\
\hline & plant & 2 & 0 & 5 & 1 & 8 & 3.00 \\
\hline & temporariness-permanence & 2 & 3 & 0 & 1 & 6 & 2.26 \\
\hline & infinity & 0 & 2 & 2 & 0 & 4 & 1.50 \\
\hline Total & & 70 & 97 & 44 & 55 & 266 & 100.00 \\
\hline
\end{tabular}

When Table 5 examined, it is seen that the most common categories classroom teacher candidates developed for the concepts of reading and writing both are grouped under the water derivatives (f:42, 15.79\%) and life (f:42, $15.79 \%$ ) categories. These categories are followed by the art (work) (f:28, 10.53\%) category. The least common categories were under the infinity category (f:6, 1.5\%). The direct quotations about the common categories for both of the concepts and their reasons given by the teacher candidates are as follows:

- I think reading is like water because water gives life to plants. Just like that, reading keeps us alive.

- I think writing is like water because writing is a necessity for me.

- I think writing is like water because it keeps us connected to life.

- I think reading is like art because it presents something that the student does not have.

- I think writing is like art because it brings forth the aesthetics in people. 
Table 6. Negative metaphors about reading and writing

\begin{tabular}{|c|c|}
\hline Reading & Writing \\
\hline \multirow{4}{*}{$\begin{array}{l}\text { Solely negative: sea, to run } \\
\text { Reasons: Does not finish, } \\
\text { having shortness of breath }\end{array}$} & Solely negative: rule, to burst with anger, work, embroidery (3), tea \\
\hline & Reasons: Obligation, difficulty, exhaustion, long labor, end of things \\
\hline & $\begin{array}{l}\text { Positive and negative together: friend, going great guns, craft, movie, sky, ocean (2), pencil, painting, } \\
\text { Turkish coffee }\end{array}$ \\
\hline & $\begin{array}{l}\text { Reasons: love and hate together, both difficult and easy, difficult or easy depending on the person, will } \\
\text { either continue or end after one time, endless, never ends, constantly written, sometimes bitter sometimes } \\
\text { sweet }\end{array}$ \\
\hline
\end{tabular}

When the negative thoughts on reading and writing in Table 6 examined, it is seen that there have been no direct negative metaphors developed about reading. However, when the reasons are examined, there are statements evoking negativity. There are two of these. In writing, there are 10 (+-) both positive and negative metaphors and 7 (-) solely negative metaphors. As is seen, there are more negative metaphors developed about the concept of reading. Some of the direct quotes are as follows:

- I think reading is like running because when you run faster, you get shortness of breath.

- I think writing is like going great guns because it is both difficult and easy.

- I think reading is like bursting with anger because it is difficult.

- I think writing is like a friend because I can transfer what I want, feel or hate.

- I think writing is like Turkish coffee because sometimes it gives us a bitter taste but sometimes a sweet taste.

\section{Results and Discussion}

When the related literature is examined, it is seen that there are studies on metaphors. However, similar to the present study, there are no metaphorical studies where two different concepts were analyzed by combining them together. In this respect, this study differs from the other metaphorical studies. In the study, it was aimed to put forth classroom teacher candidates' metaphorical perceptions about the concepts of reading and writing. In line with this general purpose, it was aimed to group metaphors about reading, metaphors about writing and metaphors about both reading and writing under categories. According to this, the most metaphors classroom teacher candidates developed about the concept of reading are respectively: water (f:22), tree (f:18), life journey (f:12), food (f:11) and travel (f:9). The metaphors developed for the concept of writing were discussed under 23 categories, and it was found that there were no metaphors directly evoking negativity. These categories are: journey, necessity, food, movement, limitation, imagination-abstractness, saving, art, health, temporariness, infinity-continuity, originality-different worlds, tranquility, light, love, freedom, seeing-looking, negativity, watching, meaning making, natural event, deservingness and dependence. Similarly, in their study named "Book as a metaphoric perception in last class of the primary and secondary students", Bektaş, Okur and Karadağ (2014) put forth positive metaphors about the concept of book. Discussing elementary school students' metaphors regarding the first reading and writing process, Kırmızı and Çelik (2015) found similar metaphors like plant, plant's development, skill, nature, fun, development, imagination, personalization, travel, sports, space, innovation, food and tree were developed by the participants. According to this result, regardless of the participants' age, similar metaphors about reading and writing come to people's minds. If metaphorical thought is shaped by conditions in which the person is in, cognitive stance and experiences the person has, as Lakoff and Johnson (2003) pointed out, it can be said that even if the age group of the sample is different, common concepts emerge from similar experiences. Likewise, while similar metaphors about reading like art, water, travel, life and painting were developed in Tiryaki and Demir's (2016) study, metaphors like love, life, painting, water, travel, imagination, eating food, new world, road and trip were developed in Mert's (2013) study. In their metaphorical study conducted with first-grade teachers on the process of teaching first reading and writing, Shaw, Barry and Mahlios (2008), the metaphor "mountain" was compared to "challenging the mountain to climb it" during the process of teaching first reading and writing.

According to the second purpose of the study, the most metaphors about the concept of writing were developed in the expression of feelings-inner world (f:72, 30.82\%), permanence (f:25, 9.40\%) and comfort (f:9.36, 9.40\%) categories. The least metaphors were grouped under the movement (f:4, 1.5\%) category. Besides, the metaphors developed about the concept of writing were discussed under 17 categories. These are: expression of 
feelings-inner world, necessity, productivity-originality, saving, eating drinking, experience, sensuality, movement, plant, art, comfort, infinity, permanence, completion, immortality, friend and guide-journey. The results of this study show similarities with the results of Tiryaki and Demir's (2016) study on the metaphorical perceptions of teacher candidates on the skill of writing. Similarly, in their study, students developed the most metaphors under the transference $(41.6 \%)$ category and the least in the infinity $(8.3 \%)$ category. In this study, too, the most metaphors were developed under the expression of feelings (30.82\%) category, which is similar to the transference category, and the least under the infinity (2.6\%) category. Also, in Mert's (2013) study, similar metaphors like mirror, water, catharsis, expression of oneself, outpouring, large body of water, pencil and trace were developed about the writing skill.

According to the third purpose of the study, the most common metaphors classroom teacher candidates developed for the concepts of reading and writing both are grouped under the water derivatives (f:42, 15.79\%) and life (f:42, 15.79\%) categories. These categories are followed by the art (work) (f:28, 10.53\%), life (f:20, $7.52 \%$ ), travel (f:20, 7.52\%) and eating-food (f:18, 10.53) categories. The least common metaphors developed under the infinity category (f:6, 1.5\%). In the common concepts used for both reading and writing, 15 categories emerged. These are water derivatives, imagination-abstractness, travel, life, necessity, art, love, immortality, tranquility, eating-food, tree, expression of feelings-inner world, saving, infinity and temporariness-permanence.

According to the fourth and last purpose, the metaphors containing negative thoughts about reading and writing were examined. There were no direct negative metaphors about reading. However, when their reasons were examined, there were only two. There were $10(+-)$ metaphorical concepts containing both negative and positive attributes about writing. There were 7 (-) metaphors evoking solely negativity.

However, it can be said that students' metaphorical perceptions regarding both reading and writing are positive. Nevertheless, compared to writing, students explained reading with less negative metaphorical concepts. This can be explained by the fact that students have more difficulty with the writing skill. In Mert's (2013) study, the writing concept was stated with negative metaphors like difficulty, torment, revenge, torture, grave stone, death and boring. It is expressed that there are various problems about the writing skill in every stage of education from elementary school to university (Bağc1, 2007; Çeçen, 2011; Çelik, 2012; Erkınay, 2011; Göçer, 2011). Among these reasons are the fact that organization about the form of the writing (paper layout, punctuation marks, writing rules, writing style) comes before the organization about the content and students cannot list their feelings and thoughts (Karatay, 2011).

As a result, metaphors can be used as powerful research tools in order to understand, determine and explain teacher candidates' perceptions regarding the concepts of reading and writing. In line with the study findings and results, the following suggestions can be given:

Academicians, administrators, teachers, students and experts designing curriculum can benefit from the findings and results of the study.

Metaphors can be used as a learning tool for students in all grades for reading and writing and courses similar to these. By this means, students' perspectives can be analyzed. The sample can be chosen from students studying different departments or faculties or students studying in different cities and their metaphors regarding reading and writing can be compared.

It is also evident that the concepts of reading and writing are associated with the metaphors developed by teacher candidates. In future studies, studies where these two concepts are discussed together can be conducted.

In this study, metaphorical perceptions were obtained through qualitative method. Future studies can be enriched studies using mixed designs, containing also the quantitative method.

The study determined that teacher candidates have more negative metaphoric perceptions about writing compared to reading. In addition to organizing reading activities with students, entertaining writing activities can be prepared to change their negative thoughts.

\section{References}

Akyol, H. (2000). "Yazı öğretimi”. Millî Eğitim. S. 146, 37-48.

Akyol, H. (2005). Türkçe ilkokuma yazma öğretimi. Ankara: PegemA Yayıncılık, 4. Baskı.

Akyol, H. (2008). Yeni programa uygun türkçe öğretim yöntemleri. Ankara: Kök Yayıncılık.

Altun, M. (2003). Edebi sanatlar: klasik edebiyat bilgisi (belagat) bağlamında. Anlam. Ocak: 19.

Arslan, M. M., \& Bayrakçı, M. (2006). Metaforik düşünme ve öğrenme yaklaşımının eğitim-öğretim açısından 
incelenmesi. Milli Ĕgitim, 35(171), 100-108.

Aydın, E., \& Sulak, S. E. (2015). Sinlf ögretmeni adaylarının “değer” kavramına yönelik metafor algıları (Metaphor perception of prospective primary school teachers for "value" concept). Bartin Üniversitesi Eğitim Fakültesi Dergisi, 4(2), 482-500. https://doi.org/10.14686/buefad.v4i2.5000148420

Aydın, F. (2010). Ortaöğretim öğrencilerinin coğrafya kavramına ilişkin sahip oldukları metaforlar. Kuram ve Uygulamada Eğitim Bilimleri (Educational Sciences: Theory \& Practice), 10(3), 1293-1322. Retrieved from http://www.kuyeb.com/pdf/tr/5658248803195b55fd1faef0dbbf0a31nFULL.pdf

Aydın, F. (2011). Üniversite Öğrencilerinin “Çevre” Kavramına İlişkin Metaforik Algıları. Doğu Coğrafya, 16(26), 25-44.

Aydın, S., \& Yalmancı, S. G. (2013). Öğretmen adaylarının biyoloji kavramina yönelik metaforik algilari/pre-service teachers' metaphorical perceptions TOWARDS biology. Mustafa Kemal Üniversitesi Sosyal Bilimler Enstitüsü Dergisi, 10(21), 209-223. Retrived from http://sbed.mku.edu.tr/article/view/1038000098/1038000017

Aydoğdu, E. (2008). İlköğretim okullarındaki ögrenci ve ögretmenlerin sahip olduklari okul algilari ile ideal okul algilarinin metaforlar (mecazlar) yardimiyla analizi. Yayınlanmamış Yüksek Lisans Tezi, Osmangazi Üniversitesi Fen Bilimleri Enstitüsü.

Bağcı, H. (2007). Türkçe öğretmeni adaylarının yazılı anlatıma ve yazılı anlatım derslerine yönelik tutumlarının değerlendirilmesi. Türklük Bilimi Araştırmaları, 21(21), 29-61.

Bektaş, M., Okur, A., \& Karadağ, B. (2014). Ilkokul ve ortaokul son sinıf öğrencilerinde metaforik algı olarak kitap. Türk Kütüphaneciliği, 28(2), 154-168.

Bruner, J. S. (1979). On knowing: Essays for the left hand (expanded ed.). Cambridge, MA: Belknap, Harvard University Press.

Çeçen, M. A. (2011). Yazma eğitimi açısından metin bilgisi. Murat Özbay (Ed.). İn Yazma eğitimi (pp. 127-146). Ankara: Pegem A Yayıncilik.

Çelik, M. E. (2012). İlköğretim sekizinci sınıf öğrencilerinin yazılı anlatım becerilerinin farklı değişkenler açısından değerlendirilmesi. International Periodical For The Languages, Literature and History of Turkish, 7(1), 727-743.

Cerit, Y. (2008). Öğretmen Kavramı İle İlgili Metaforlara İlişkin Öğrenci, Öğretmen ve Yöneticilerin Görüşleri. Türk Eğitim Bilimleri Dergisi, sayl, 6(4), 693-712.

Clark, G. J. (2010).The relationship between handwriting, reading, fine motor and visual-motor skills in kindergarteners. Graduate Theses and Dissertations. 11399. Retrieved from http://lib.dr.iastate.edu/etd/11399

Ekiz, D., \& Koçyiğit, Z. (2013). Sınıf öğretmenlerinin “öğretmen” kavramına ilişkin metaforlarının tespit edilmesi. Kastamonu Ĕgitim Dergisi, 21(2), 439-458.

Erkınay, H. K. (2011). Türkçe öğretmenlerinin yazım kılavuzu kullanma konusundaki tutum ve görüşleri. The Journal of Academic Social Science Studies, 4(1), 1-24. http://dx.doi.org/10.9761/JASSS_30

Eroğlu, Z. D. (2013). Öğretmen adaylarının okuma alışkanlıkları ile doğru yazma becerileri arasındaki ilişki. Electronic Turkish Studies, 8(9).

Geçit, Y., \& Gençer, K. (2011). Sınıf öğretmenliği 1. sınıf öğrencilerinin coğrafya algılarının metafor yoluyla belirlenmesi (Rize Üniversitesi örneği). Marmara Coğrafya Dergisi, 23, 1-19.

Göçer, A. (2011). Öğrencilerin yazılı anlatım çalışmalarının Türkçe öğretmenlerince değerlendirilmesi üzerine. Ondokuz Mayls Üniversitesi Ĕ̈itim Fakültesi Dergisi, 30(2), 71-97.

Göçer, A., \& Tabak, G. (2013). Öğretmen adaylarının görsel okuryazarlık ile ilgili algıları. Adıyaman Üniversitesi Sosyal Bilimler Enstitüsü Dergisi, 2013(11), 517-541. https://doi.org/10.14520/adyusbd.450

Gömleksiz, M. N., Kan, A. Ü., \& Öner, Ü. (2012). İlköğretim Öğrencilerinin Sosyal Bilgiler Dersine İlişkin Metaforik Alglarl (Metaphorical Perceptions of Elementary School Students toward Social Studies Course).

Gün, M. (2012). İlköğretim ikinci kademe Türkçe dersi okuma metinlerinde karşılaşılan sorunlar. Dil ve Edebiyat Ĕ̈itimi Dergisi, 1(4), 1-21. 
Güneş, F. (2007). Türkçe Öğretimi ve Zihinsel Yapılandırma. Ankara: Nobel Yayın Dağıtım.

Harris, T., \& Hodges, R. (Eds.). (1995). The literacy dictionary: The Vocabulary of Reading and Writing (p. 207). Newark, DE: International Reading Association.

İlter, İ. (2015). Primary School Teacher Candidates' Metaphorical Perceptions Related to Multigrade Classes Concept. Elementary Education Online, 14(4), 1450-1468.

Kahyaoğlu, M. (2015). İlköğretim Öğrencilerinin Doğa Kavramına İlişkin Algılarının Metaforlar Yoluyla İncelenmesi. Electronic Turkish Studies, 10(11). https://doi.org/10.7827/TurkishStudies.8526

Kalyoncu, R. (2013). Sınıf Öğretmeni Adaylarının Â Sanat Eğitimi Dersiâ Kavramına İlişkin Metaforları. Education Sciences, 8(1), 90-102.

Karaırmak, Ö., \& Güloğlu, B. (2012). Metafor: Danışan ve psikolojik danışman arasındaki köprü. Türk Psikolojik Danışma ve Rehberlik Dergisi, 4(37), 122-135. Retrieved from file:///C:/Users/Hp/Downloads/163-202-1-PB\%20(1).pdf

Karatay, H. (2011). 4+1 planlı yazma ve değerlendirme modelinin öğretmen adaylarının yazılı anlatım tutumlarını ve yazma becerilerini geliştirmeye etkisi. Turkish Studies, 6(3), 1029-1047.

Kavcar, C., Oğuzkan, F., \& Sever S. (1997). Türkçe öğretimi-Türkçe ve sinıf öğretmenleri için. Ankara: Engin Yayınevi.

Kırmızı, F. S., \& Çelik, D. (2015). İlkokul Öğrencilerinin İlkokuma Yazma Öğrenme Sürecine İlişkin Metafor Algıları. Electronic Turkish Studies, 10(10).

Korkmaz, F., \& Bağçeci, B. (2013). Lise Öğrencilerinin “Üniversite”Kavramına İlişkin Metaforik Algıların İncelemesi. doi: 10.14686/201312025. Bartın Üniversitesi Eğitim Fakültesi Dergisi, 2(1), 187-204. https://doi.org/10.14686/201312025

Lakoff, G., \& Johnson, M. (2003). Metaphors we live by. G.Y. Demir (Çev.). İstanbul: Paradigma Yayıncılık. https://doi.org/10.7208/chicago/9780226470993.001.0001

Levine, P. M. (2005). Metaphors and images of classrooms. Kappa Delta Pi Record, 41(4), 172-175. https://doi.org/10.1080/00228958.2005.10532066

Maden, S. (2012). Ekran okuma türleri ve Türkçe öğretmeni adaylarının ekran okumaya yönelik görüşleri. Dil ve Edebiyat Ĕ̈itimi Dergisi, 1(3), 1-16.

MEB. (2005). İlköğretim Türkçe Dersi Öğretim Programı ve Kılavuzu (1-5. Sinıflar). Ankara.

Mert, E. L. (2013). Türkçe Ögretmen Adaylarının Dört Temel Dil Becerisine İliskin Algılarının Metaforlar Aracilığıla Analizi. Journal of International Social Research, 6(27).

Miles, M. B. \& Huberman, A.M. (1994). Qualitative data analysis: An expanded sourcebook (2nd ed.). Calif.: Sage Publications.

Oflaz, G. (2011). İlköğretim Öğrencilerinin 'Matematik' ve 'Matematik Öğretmeni' Kavramlarına İlişkin Metaforik Algilart. 2nd International Conference on New Trends in Education and Their Implications 27-29 April, 2011 Antalya-Turkey

Özdemir, E. (2011). Eleştirel Okuma. Ankara: Bilgi Yayınevi.

Pala A., Yıldız H. (2012). Üniversite Öğrencilerinin Okuma AlıĢkanlı̆̆g: Celal Bayar Üniversitesi Örneği. Akademik Arastirmalar Dergisi. Sayl, 53, 15-26.

Razon, N. (1980). Okuma bozukluklart ve nedenleri. Istanbul:Pedagoji Dergisi, Sayı:1

Saban, A. (2008). Okula ilişkin metaforlar, Kuram ve Uygulamada Eğitim Yönetimi, 55, 459-496.

Şahin, D., \& Tüzel, E. (2014). İlköğretim Birinci Kademe Öğrencilerinin Okul Yöneticilerine İlişkin Metaforları. Adryaman Üniversitesi Sosyal Bilimler Enstitüsü Dergisi, 2014(17). https://doi.org/10.14520/adyusbd.736

Shaw, D. M., \& Mahlios, M. (2008). "Pre-service teachers' metaphors of teaching and literacy". Reading Psychology, 29, 31-60. https://doi.org/10.1080/02702710701568397

Soysal, D., \& Afacan, O. (2012). Metaphors used by primary school students to describe "Science and Technology lesson" and "Science and Technology teacher". Mustafa Kemal University Journal of Social Sciences Institute, 9(19), 287-306.

Tiryaki, E. N., \& Demir, A. (2016). Türkçe Öğretmeni Adaylarının Yazma Becerisine Yönelik Metaforik 
Algılar1/Turkish Teacher Candidates' Metaphorical Perceptions Related to Writing Skills. Mustafa Kemal Üniversitesi Sosyal Bilimler Enstitüsü Dergisi, 13(33).

TDK. (2011). Büyük Türkçe Sözlük. Ankara: Türk Dil Kurumu.

Ulusoy, M. (2013). Sınıf öğretmeni adaylarının Türkçe ve öğrenme alanları ile ilgili metaforları. Akdeniz Eğitim Araştırmaları Dergisi, 14, 1-18.

Ünal, A., Yıldırım, A., \& Çelik, M. (2010). Ilköğretim okulu müdür ve öğretmenlerinin velilere ilişkin algılarının analizi. Selçuk Üniversitesi Sosyal Bilimler Enstitüsü Dergisi, 23, 261.

Ünalan, Ş. (2006). Türkçe Öğretimi. Ankara: Nobel Yayın Dağıtım.

Ungan, S. (2008). Okuma Alışkanlığımızın Kültürel Altyapısı. Gaziantep Üniversitesi Sosyal Bilimler Dergisi, 7(1), 218-228.

Ünüvar, P., \& Çelik, K. (1999). İlkokuma - yazma öğretimi. Burdur: Meb Yayınları.

Yalçın, M., \& Erginer, A. (2012). İlköğretim okullarında okul müdürüne ilişkin metaforik algılar. Öğretmen Eğitimi ve Eğitimcileri Dergisi, 1(2), 229-256.

Yalçınkaya, E. (2013). Tarih kavramına yönelik sınıf öğretmeni adaylarının ürettikleri metaforların incelenmesi. Zeitschrift für die Welt der Türken/Journal of World of Turks, 5(3), 95-112.

Yıldırım, A., \& Şimşek, H. (2013). Sosyal bilimlerde nitel araştırma yöntemleri. Ankara: Seçkin.

Yıldız, C., Okur, A., Arı, G., \& Yılmaz, Y. (2006). Yazma öğretimi. Yeni öğretim programına göre kuramdan uygulamaya türkçe öğretimi (Ed. Cemal Yıldız, pp. 203-276). Ankara: PegemA Yayıncılık.

Yılmaz, F., Göçen, S., \& Yılmaz, F. (2013). Öğretmen adaylarının öğretmen kavramına ilişkin algıları: bir metaforik çalışma. Mersin Üniversitesi Eğitim Fakültesi Dergisi, 9(1).

Zuniga, M. E. (1992). Using metaphors in therapy: Dichos and Latino clients. Social Work, 37(1), 55-60. https://doi.org/10.1093/sw/37.1.55

\section{Copyrights}

Copyright for this article is retained by the author(s), with first publication rights granted to the journal.

This is an open-access article distributed under the terms and conditions of the Creative Commons Attribution license (http://creativecommons.org/licenses/by/4.0/). 